\title{
Features of the fault system and its relationship with migration and accumulation of hydrocarbon in Liaodong Bay
}

\author{
Xu Guosheng*', Ma Ruolong¹, Gong Deyu' ${ }^{1}$, Zhou Donghong², Li Jianping², \\ Guo Yonghua ${ }^{2}$, Yuan Haifeng ${ }^{1}$ and Wu Changrong ${ }^{1}$
}

\author{
${ }^{1}$ State Key Laboratory of Oil and Gas Reservoir Geology and Exploitation, Chengdu University of Technology, Chengdu, \\ Sichuan 610059, China \\ ${ }^{2}$ Exploration and Development Research Institute, Tianjin Branch of CNOOC (China) Co., Ltd., Tanggu, Tianjin 300452, \\ China
}

(C) China University of Petroleum (Beijing) and Springer-Verlag Berlin Heidelberg 2011

\begin{abstract}
The fault system of Liaodong Bay developed extensively under the control of the Tanlu Fault. The fault system can be grouped into strike-slip faults of grade I, trunk faults of grade II and branch faults (induced faults) of grade III respectively based on its developmental scale. The faults of grade I and II were deep, early and large while the faults of grade III were shallow, late and small. The formation, evolution and distribution features played a significant role in controlling the migration of oil and gas in both horizontal and vertical directions. The fluid transfer in the fault system occurred in the process of faulting. The strike-slip and trunk faults moved actively forming predominant pathways for oil and gas migration. The branch faults, with weak activity, generally controlled the development of traps and were beneficial for the accumulation and preservation of oil and gas. The faults of grade I and II formed the major migration pathways for oil and gas, but their fault activity rates appeared to vary along their strikes. The zones with a relatively low fault activity rate might be favorable for oil and gas accumulation. When the activities of strike-slip, trunk, and branch faults came to a halt, the fault seal behavior had a vitally important effect on the accumulation of oil and gas. The controlling role of the fault over fluid distribution was further analyzed by calculating the fault activity quantitatively.
\end{abstract}

Key words: Liaodong Bay, fault system, fault activity rate, fault seal behavior, migration and accumulation of oil and gas

\section{Introduction}

There was a multitude of hydrocarbon-bearing series in the vertical direction in Liaodong Bay and several oil and gas-producing strata from the Neogene system to the Archaean group. Success was achieved in extensive oil and gas exploration in Liaodong Bay. Meanwhile, the whole Liaodong Bay, influenced by the large Tanlu strike-slip fault, developed a complicated fault system which has a close relationship to the wide distribution of hydrocarbon reservoirs and multiple oil and gas-bearing series in the vertical direction in Liaodong Bay. Qi et al (2008) proposed that the Tanlu Fault Zone in Cenozoic basins of Bohai Sea was mainly composed of basement faults (zones) NNE trending in the eastern basin, through which the Cenozoic extensional

*Corresponding author. email: xgs@cdut.edu.cn Received March 7, 2011 faults were dissected and transformed. The Tanlu Fault Zone was characterized by dextral strike-slip displacement. The formation of Paleogene faults was mainly dominated by these extensional faults. In the Paleogene, the extension and strike-slip of the Tanlu Fault Zone not only controlled the distribution of depressions and source rocks, but also was in communication with source rocks, becoming a dominant path for hydrocarbon accumulation in different periods. Gong et al (2007) considered that the successive activities of Paleogene faults and their connection to Neogene faults were the key to hydrocarbon accumulation in the Neogene. However, a number of traps created by Neogene faults were located in the sags far away from the major fault without any connection, resulting in no oil and gas accumulation.

Some researchers have conducted considerable painstaking research on the relationship between faults and migration, accumulation as well as preservation of oil and gas. Lv and $\mathrm{Hu}$ (2002) put forward a quantitative approach to 
evaluating vertical seal behavior of fault zones by studying the displacement pressure of fault fillings. Smith $(1966,1980)$ built up a theoretical model of fault sealing, holding that the displacement pressure of juxtaposed layers on both sides of the fault controlled the fault seal behavior. Bouvier and Kaars-Sijp (1989) proposed that the relative sealing degree of faults could be estimated by clay smear potential (CSP). Lindsay et al (1993) pointed out that the clay smear of a fault could strengthen the seal behavior and prevent oil and gas migrating laterally. He also raised shale smear factor (SSF) to characterize the fault sealing. Yielding et al (1997) came up with smear gouge ratio (SGR) to show the proportion of shale or clay that might be entrained in the fault zone by a variety of mechanisms to predict fault seal behavior. These studies are focused on the static analysis of faults; however, the fault activity and its activity rate could also affect fluid flow along or across the fault. During quiescent periods of a fault, the fluid activities along the fault plane were generally sealed or only of weak permeability; while the fluid transfer occurred and obviously increased during faulting (Constantin et al, 2004). This paper, on the basis of the formation and evolution as well as distributive features of the fault system in Liaodong Bay, analyzed the relationship between the fault conducting system and migration, accumulation as well as preservation of oil and gas from both dynamic and static perspective.

\section{Geological setting}

The Bohai Bay basin, a large rifted basin, was formed in the Middle Cenozoic. Liaodong Bay is located in the north of the basin running from NNE to NE. Its main body lies in the western side of the Tanlu Fault Zone and part of Liaodong Bay is in the faults. Liaodong Bay consists of three structural levels on profile; namely, former Paleogene basement and Paleogene and Neogene cap rocks (Table 1). On the basis of two groups of shear faults forming before and during the Yanshan movement in Liaodong Bay, the faulted basin which had begun to develop in the Jurassic and Cretaceous was further developed in the Paleogene and formed a large tectonic system with clustered parallel vertical faults. The whole subsided in the Neogene moving to the developmental stage of basin depression. After several decades of exploration, a host of oil and gas fields have been discovered one after another near the two sides of the Tanlu strike-slip fault zone and its derivative fault zones in Liaodong Bay. Being one of the most significant oil and gas producing areas, Liaodong Bay still has biggish exploration potential.

Table 1 The main strata in Liaodong Bay Area

\begin{tabular}{|c|c|c|c|c|c|c|}
\hline Erathem & System & Series & Formation & Member & $\begin{array}{c}\text { Sub- } \\
\text { member }\end{array}$ & Code \\
\hline \multirow{15}{*}{ Cenozoic } & Quaternary & & Pingyuan & & & Qp \\
\hline & No & Mis & $\mathrm{C}$ & & Upper & $\mathrm{N}_{1} \mathrm{~g}^{\mathrm{U}}$ \\
\hline & Neogene & IVIOCEII & vuartao & & Lower & $\mathrm{N}_{1} \mathrm{~g}^{\mathrm{L}}$ \\
\hline & \multirow{12}{*}{ Paleocene } & \multirow{4}{*}{ Oligocene } & \multirow{4}{*}{ Dongying } & $1 \mathrm{st}$ & & $\mathrm{E}_{3} \mathrm{~d}^{1}$ \\
\hline & & & & \multirow{2}{*}{2 nd } & Upper & $\mathrm{E}_{3} \mathrm{~d}^{2 \mathrm{U}}$ \\
\hline & & & & & Lower & $\mathrm{E}_{3} \mathrm{~d}^{2 \mathrm{~L}}$ \\
\hline & & & & $3 r d$ & & $\mathrm{E}_{3} \mathrm{~d}^{3}$ \\
\hline & & \multirow{8}{*}{ Eocene-Palaeocene } & \multirow{4}{*}{ Shahejie } & $1 \mathrm{st}$ & & $\mathrm{E}_{2} \mathrm{~s}^{1}$ \\
\hline & & & & 2nd & & $\mathrm{E}_{2} \mathrm{~s}^{2}$ \\
\hline & & & & \multirow{3}{*}{$3 r d$} & Upper & $\mathrm{E}_{2} \mathrm{~s}^{3 \mathrm{U}}$ \\
\hline & & & & & Middle & $\mathrm{E}_{2} \mathrm{~s}^{3 \mathrm{M}}$ \\
\hline & & & \multirow{4}{*}{ Kongdian } & & Lower & $\mathrm{E}^{2} \mathrm{~s}^{3 \mathrm{~L}}$ \\
\hline & & & & \multirow{3}{*}{4 th } & Upper & $\mathrm{E}_{2} \mathrm{~s}^{3 \mathrm{U}}$ \\
\hline & & & & & Lower & $\mathrm{E}_{2} \mathrm{~s}^{3 \mathrm{~L}}$ \\
\hline & & & & & & $\mathrm{E}_{1-2} \mathrm{~K}$ \\
\hline Precambrian-Archaean & & & & & & Pt-Ar \\
\hline
\end{tabular}

\section{Features of the fault system in Liaodong Bay}

\subsection{Grading and distribution features of the fault system}

In order to make the relationship clear between the fault system in Liaodong Bay and the building block distribution of the sedimentary basin as well as the fault distribution in the Paleogene, Neogene, and Quaternary, the faults are classified into strike-slip faults of grade I, trunk faults of grade II and branch faults (induced faults) of grade III respectively according to different cutting horizons of faults (Fig. 1).

Cutting through the basement, the grade I faults were 


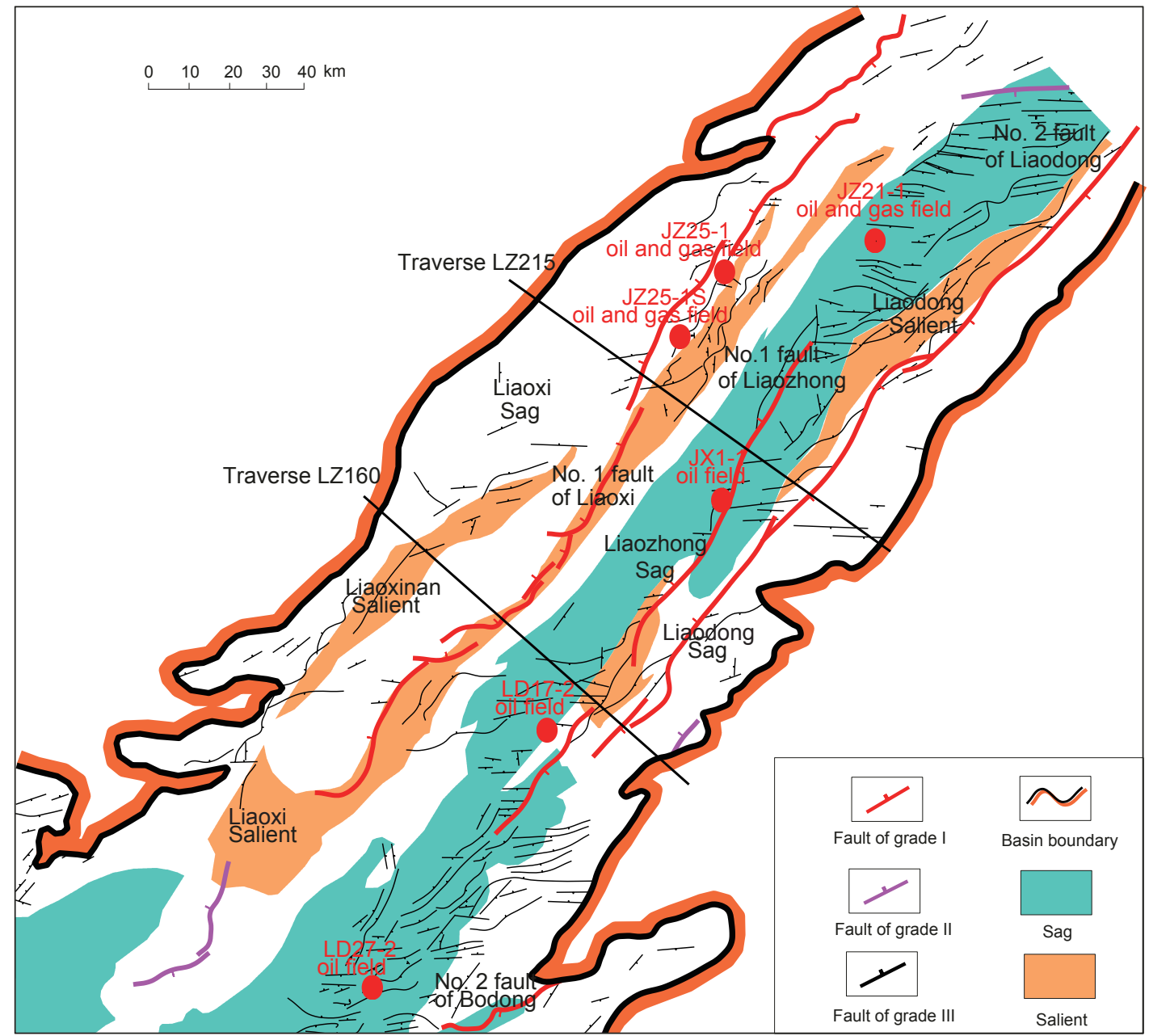

Fig. 1 Fault system of Liaodong Bay in the late $\mathrm{N}_{1} \mathrm{~g}$

formed at the end of the Mesozoic and then went on with inherited development, most of which were strike-slip faults controlling sag and salient evolution. From perspective of fault scale, the grade I faults in Liaodong Bay, chiefly including No. 1, 2, and 3 of Liaoxi, No. 1 and 2 of Liaozhong, No. 1 and 2 of Liaodong, No. 1 of Qinnan and No. 2 of Bodong etc., are distributed towards NNE-NE and controlled the whole tectonic framework of this area. The Tanlu Fault Zone in the Neogene runs NNE across Liaodong Bay and had a close relationship with the tectonic unit distribution of the sedimentary basin. In Liaodong Bay, there developed large quantities of en echelon derivative faults which were different in developing places and degree among different periods (Fig. 1). Two former Paleogene relief belts in the east and west with a sag belt in the middle made up the whole tectonic framework. The strike of the grade II faults is the same to that of the grade I faults, NNE to NE. Compared with the grade I faults, the grade II faults have a small number of fractured horizons and a short distance of planar extension. In the northern part of Liaodong Bay, faults of grade II were mainly developed in the Shahejie Formation, while those were most developed in the mid-shallow layers of central and southern Liaodong Bay. The grade III faults are derivative faults formed in the late active period of the Tanlu Fault, characterized by the most intensive development.
Distributed in two strike directions, i.e., NNE-NE and nearly EW trending, the grade III faults were mainly developed in shallow strata, such as the first and second members of the Dongying Formation as well as the Guantao Formation. The faults of grade II and III were often converged with the trunk fault in deep layers, shown with negative flower structures in the section.

\subsection{Profile structure and subsectional features of the fault system}

Based on the analysis of several WNW-ESE seismic profiles across Liaodong Bay, the section structure of the Tanlu Fault Zone (Liaodong Bay section) has been studied and the geological features of the Tanlu Fault Zone in different sections have been further compared (Table 2 and Fig. 2). The Tanlu Fault Zone developed three branches on the profile with relatively upright fault section. The western branch, a negative flower structure, (No. 1 fault of Liaozhong) lies in the center of the Liaozhong Sag. Two branches in the east part (No. 2 fault of Liaozhong, No. 2 fault of Liaodong), located on both sides of the Liaodong Salient, were the boundary faults between the Liaodong Salient and the Liaozhong Sag in the west as well as the Liaodong Sag in the east. The northern section of the Tanlu Fault Zone (No. 2 fault of Liaozhong) exhibited a negative flower structure and 


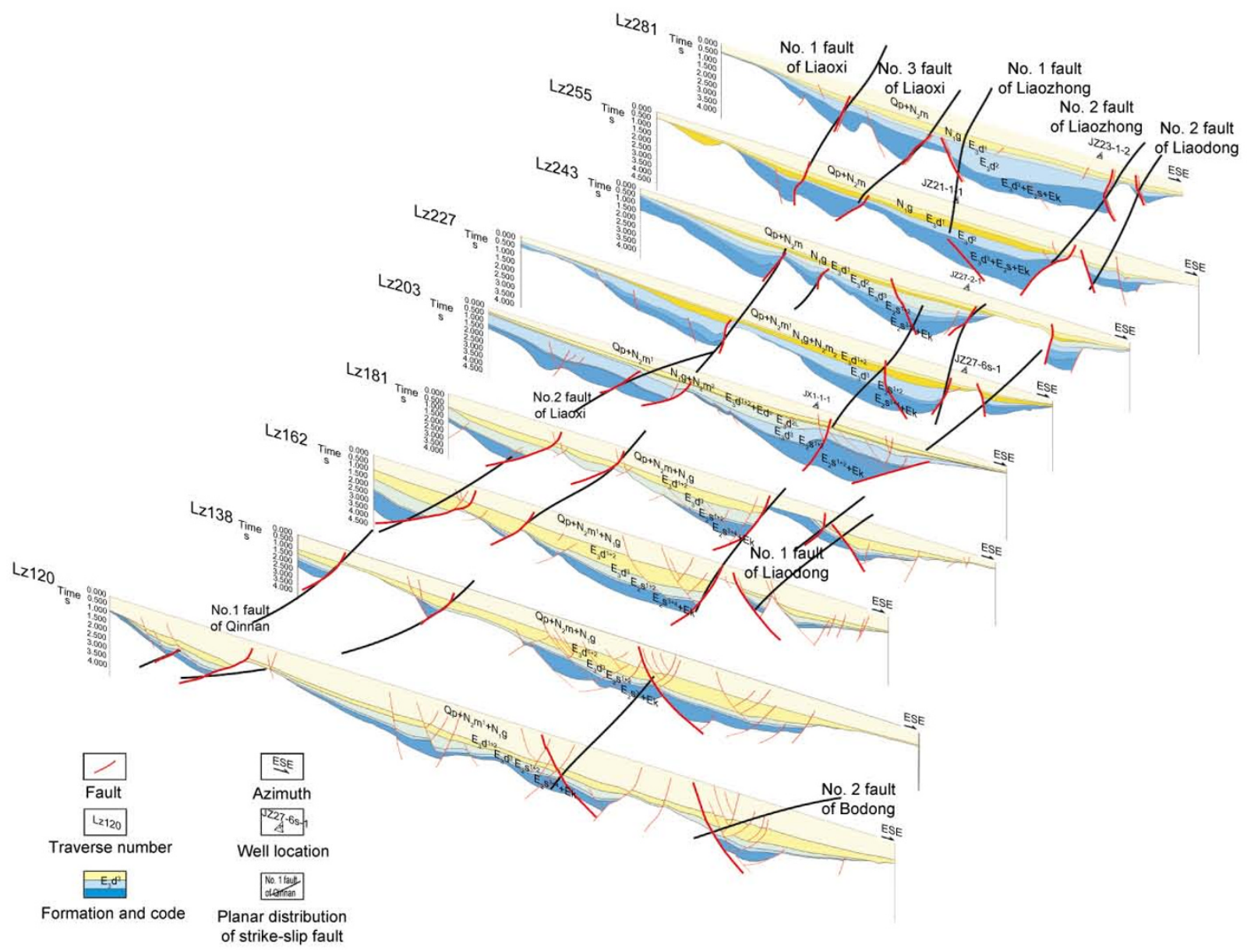

Fig. 2 The characteristics of the Tanlu Fault Zone

the southern section was characterized by a normal fault on the profile. No. 2 fault of Liaodong is listric, slightly spade shaped, with the upper steep and the lower smooth form near the northern area. The analysis of a series of profile structures in Liaodong Bay shows that the Tanlu Fault Zone is clearly characterized by differential deformation of zoning and segmentation; furthermore, it had diverse effects on deformation features of strata in different ages vertically. The Tanlu Fault Zone (Liaodong Bay section) could be roughly divided into three sections of south, center and north with the boundary of LZ160 and LZ215 counting lines respectively (Table 2, Fig. 2).

In the southern section of the Tanlu Fault Zone (Liaodong Bay section), the Liaodong Salient was not developed at all. The Liaozhong Sag was directly apart from the Liaodong Sag with No. 1 fault of Liaozhong as its boundary, showing a typical negative flower structure on the profile. The Liaozhong Sag and the Shahejie Formation in the Liaodong Sag deposited a little bit slightly, showing a protuberant structure relevant to the negative flower structure. The burial depth of the Neogene tended to be low in the western zone and the Paleogene is missing in the Liaoxi Salient (Qi et al, 2008).

Compared with the southern section, the burial depth of the Neogene sediments in the middle section of the Tanlu Fault Zone (Liaodong Bay section) deepened, with the thick Shahejie Formation in the sag and the salient. No. 1 fault of Liaozhong experienced severe transpression in the late period and was reversed at the end of the Dongying period. The middle section could be further divided into subsections of middle-south and middle-north. Three salients, Liaodong Salient, Liaoxi Salient, and Liaoxinan Salient, appeared in the middle-southern subsection, which was characterized by the structure of "four sags with three salients" (Table 2 and Fig. 2). The middle-northern subsection only had the Liaoxi Salient and the Liaoxinan Salient pinched out horizontally, while the Liaodong Salient was separated by No. 2 fault of Liaodong.

The Tanlu Fault Zone mainly consists of No. 1, No. 2 faults of Liaozhong and No. 2 fault of Liaodong in the northern section, manifesting the tectonic feature of "three sags with two salients" (Table 2, Fig. 2). Compared with the middle section, the burial depth of the Neogene sediments went on deepening here and the Shahejie Formation deposited on the Liaoxi Salient. No. 1 fault of Liaozhong shifted from upstanding to east inclination with weakening strike-slip. While No. 2 faults of Liaozhong and Liaodong underwent severe strike-slip movement and became the main strikeslip faults instead of No. 1 fault of Liaozhong. Faults in the late period chiefly assembled around the periphery of the Liaodong Salient (Table 2, Fig. 2).

In general, the Tanlu Fault Zone extended across the Liaozhong Sag from SW to NE at the end of sedimentary periods of the third member of the Shahejie Formation $\left(\mathrm{E}_{2} \mathrm{~s}^{3}\right)$, the Dongying Formation, and the Guantao Formation. The 
Table 2 Subsectional deformation features of the Tanlu Fault

\begin{tabular}{|c|c|c|c|}
\hline & Fault & $\begin{array}{l}\text { The distribution } \\
\text { of sags and salients }\end{array}$ & Structural and sedimentary features \\
\hline \multirow{3}{*}{ 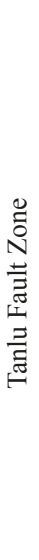 } & $\begin{array}{l}\text { Northern } \\
\text { section }\end{array}$ & $\begin{array}{l}\text { Liaodong Salient } \\
\text { Liaoxi Salient } \\
\text { Liaodong Sag } \\
\text { Liaozhong Sag } \\
\text { Liaoxi Sag }\end{array}$ & $\begin{array}{l}\text { No. } 1 \text { fault of Liaozhong tends generally to plunge in the NE direction; } \\
\text { No. } 2 \text { fault of Liaozhong and No. } 2 \text { fault of Liaodong became main strike-slip faults; } \\
\text { Negative flower structures were not well developed in this area; } \\
\text { Cenozoic Erathem deepened; } \\
\text { The Shahejie Formation deposited on the Liaoxi Salient }\end{array}$ \\
\hline & $\begin{array}{l}\text { Middle } \\
\text { section }\end{array}$ & $\begin{array}{l}\text { Liaodong Salient } \\
\text { Liaoxi Salient } \\
\text { Liaoxinan Salient } \\
\text { Liaodong Sag } \\
\text { Liaozhong Sag } \\
\text { Liaoxi Sag }\end{array}$ & $\begin{array}{l}\text { The No. } 1 \text { fault of Liaozhong was overturned seriously in the late Donying stage; } \\
\text { Negative flower structures were comparatively developed in this area; } \\
\text { Cenozoic Erathem deepened; } \\
\text { Shahejie Formation became thicker both in the salients and sags }\end{array}$ \\
\hline & $\begin{array}{l}\text { Southern } \\
\text { section }\end{array}$ & $\begin{array}{l}\text { Liaoxi Salient } \\
\text { Liaodong Sag } \\
\text { Liaozhong Sag } \\
\text { Liaoxi Sag }\end{array}$ & $\begin{array}{l}\text { Negative flower structures were well developed in this area; } \\
\text { The Shahejie Formation became thinner in the sags; } \\
\text { The salients lack the Eogene deposits; } \\
\text { Paleocene deposits were lost in the salients }\end{array}$ \\
\hline
\end{tabular}

burial depth of the Cenozoic continued to increase, and the sediments of Shahejie Formation continued to thicken, leading to a slip with migration trend from the central depression to both sides. Grade I and II faults of the Tanlu Fault Zone in Liaodong Bay were more widely and continuously distributed at the end of the sedimentary period of the third member of the Shahejie Formation $\left(\mathrm{E}_{2} \mathrm{~s}^{3}\right)$ than those distributed at the end of the sedimentary periods of the Dongying Formation and the Guantao Formation. However, the grade III faults of the Tanlu Fault Zone in Liaodong Bay were located at the end of the sedimentary periods of the Dongying Formation and the Guantao Formation more intensively, extensively and regularly than that at the end of the sedimentary period of the third member of the Shahejie Formation $\left(\mathrm{E}_{2} \mathrm{~s}^{3}\right)$. This reflects that the grade I and II faults occurred deeper and earlier with greater movement, while the faults of grade III occurred shallower and later with smaller throws, which determined the different effects of various grades of sub-faults on hydrocarbon accumulation (Ghosh and Mitra, 2009; Mora, et al, 2010).

\section{Relationship between fault activity rate and the migration and accumulation of oil and gas}

In the Paleogene, the extension and strike-slip of the Tanlu Fault Zone, played the most important role in the formation of oil and gas reservoirs in different periods and linked up hydrocarbon rocks as well. The traps near this kind of faults (the grade I and II faults) were likely to form oil and gas reservoirs; otherwise, the probability became low. More than $80 \%$ of the oil and gas reservoirs found in the Bohai Sea, dominated by communication and migration of fault, were close to the trunk fault, such as SZ36-1, JZ25-1, JZ202, LD27-2, JX1-1 oil and gas field. Since the Miocene, the Tanlu Fault with successive activity and faults in neotectonic comprised the major communication system of oil and gas accumulation in the Neogene. The neotectonic movement controlled the accumulation of oil and gas in the late period in Bohai Bay. The majority of oil and gas accumulated in the
Guantao Formation and the Minghuazhen Formation in the Neogene. The successive activities of the Paleogene fault and its connection with the Neogene fault were the key to oil and gas accumulation in the Neogene. Almost all Neogene oil and gas fields discovered belong to this kind of accumulation model. However, some traps, made up of the Neogene faults, located in sags far away from the trunk fault, have not communicated with the trunk fault, so they failed to form oil and gas reservoirs, such as LD17-2 structure (Gong et al, 2007).

\subsection{Fault activity rate and the migration and accumulation of oil and gas in different periods}

The activity of faults, which cut through the hydrocarbon rocks during hydrocarbon discharge period, decided the migration of oil and gas (Bekele et al, 1999; Wan et al, 2010). On the whole, the grades I and II fault activity velocity in Liaodong Bay played a key role in oil and gas migration. These two grades of faults were major passages for the migration of oil and gas from hydrocarbon rocks to traps. However, what is worth noticing is that the activities of these faults were also highly unbalanced - sometimes active, sometimes weak and sometimes even still. This variation of fault activity resulted in significant differences in abundance of oil and gas distributed in Bohai Bay (Weber et al, 1978; Du et al, 2007; Xu et al, 2008). The fault activity rate can be used to characterize the fault activity and to compare the fault activities in different development periods and locations. The fault activity rate is defined as the ratio between the throw of a certain stratigraphic unit in a specific period due to internal fault activity and the corresponding sedimentary time. The calculation equation is expressed as follows:

Fault activity rate $=($ the thickness of the hanging wall the thickness of the footwall) / sedimentary time

Using three-dimensional seismic data, equally spaced seismic sections were selected along the Inline direction. VSP data were used to convert time sections into depth sections, and then the thicknesses of the fault hanging wall and the footwall were calculated. Combined with the stratum sedimentary time (Table 1 ), the fault activity rates of the 
faults of Liaoxi 1 and 2, and Liaozhong 1 were calculated. Taking No. 1 fault of Liaoxi as an example (Table 3), it could be seen from the calculation results of the fault activity rate that different activity rates corresponded to different sedimentary periods $\left(E_{2} s^{3}-E_{3} d^{1}\right)$. The fault activities in $E_{2} s^{3}$ and $E_{3} d^{2}$ were intensified with the maximum fault rate at $132.2 \mathrm{~m} / \mathrm{Ma}$, while those in $\mathrm{E}_{2} \mathrm{~s}^{1}$ to $\mathrm{E}_{3} \mathrm{~d}^{1}$ were weakened. Till the final sedimentary period of $E_{3} d^{1}$, the fault was still active, but with a very small activity rate.

For example, No. 1 and 2 faults of Liaoxi were both major subbasin-controlling faults of the Liaoxi Sag and the grade I faults of long-term successive movement (the basementMinghuazhen Formation). The JZ25-1S oil and gas field is located on both sides of these two faults which were still moving in the period of hydrocarbon migration. These were favorable for oil and gas migration from the Liaoxi Sag to the low swell in Liaoxi and became the most important migration passage in this area (Fig. 3). These two faults were active as a whole and in favor of oil and gas transfer, but their activity rate varied over time. The fault activities have gradually weakened so oil and gas could not migrate to some parts due to insufficient connectivity. Hence, in the JZ25$1 \mathrm{~S}$ oil and gas field, oil and gas had not accumulated in the Guantao Formation and the Minghuazhen Formation, but in the Archaean granite buried hills and the Paleogene Shahejie Formation (Figs. 3 and 4) (Ye, 2007; Lu, et al, 2010).
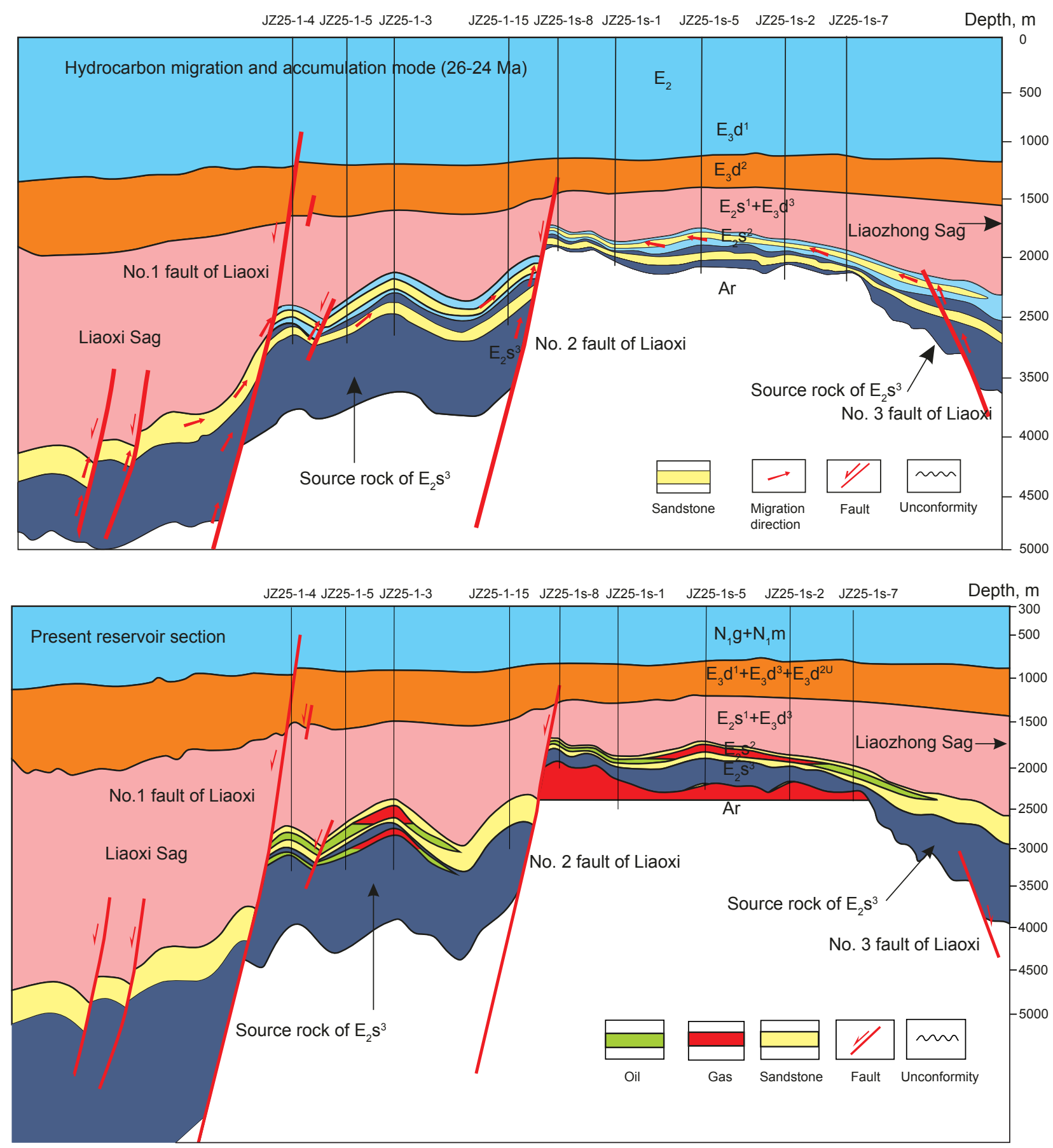

Fig. 3 Hydrocarbon migration and accumulation mode in JZ25 Area. The upper one is the charge and migration situation 26-24 Ma ago while the lower one is the present reservoir section 


\subsection{Activity rate at different strikes and oil \& gas migration and accumulation}

In general, the faults of grades I and II were active and exhibited a significant control over migration of oil and gas; while the faults of grade III were not active, which was favorable for oil and gas accumulation. However, the fault activity rate often varied along the strike of grade I faults, which would affect the migration and accumulation of oil and gas. For example, the JX1-1 oil field, located in the central subsag of the Liaozhong Sag and divided into two blocks (east and west blocks) by No. 1 fault of Liaozhong, which was a fault of grade I with successive development going towards NNE (Fig. 1). The activity rate of No. 1 fault of Liaozhong appeared high in the center and low on both sides in the deposition period of the first member of the Shahejie Formation (Fig. 5). The maximum rate in the center reached up to near $160 \mathrm{~m} / \mathrm{Ma}$ and the minimum in the northern section was only $20 \mathrm{~m} / \mathrm{Ma}$, which was beneficial to oil and gas accumulation. The JX1-1 oil field is just located at the zone with a low fault activity rate (Zhou, 2007; Hao et al, 2009a; 2009b).

Table 3 Statistics of fault activity rate of in No. 1 fault of Liaoxi

\begin{tabular}{|c|c|c|c|c|c|}
\hline Period & Line & $\begin{array}{l}\text { The thickness } \\
\text { of the hanging wall, } \mathrm{m}\end{array}$ & $\begin{array}{l}\text { The thickness } \\
\text { of the footwall, } \mathrm{m}\end{array}$ & $\begin{array}{l}\text { Deposition } \\
\text { time, Ma }\end{array}$ & $\begin{array}{l}\text { Fault activity } \\
\text { rate, } \mathrm{m} / \mathrm{Ma}\end{array}$ \\
\hline \multirow{4}{*}{$\mathrm{E}_{2} \mathrm{~s}^{3}$ period } & 1590 & 428.5 & 363.2 & \multirow{4}{*}{4} & 16.3 \\
\hline & 1670 & 513.9 & 470.0 & & 10.9 \\
\hline & 1710 & 751.2 & 590.3 & & 40.2 \\
\hline & 1750 & 803.0 & 610.2 & & 48.2 \\
\hline \multirow{9}{*}{$\mathrm{E}_{2} \mathrm{~s}^{2}$ period } & 1430 & 156.9 & 115.0 & \multirow{9}{*}{2} & 21 \\
\hline & 1470 & 127.9 & 117.5 & & 5.2 \\
\hline & 1510 & 147.3 & 128.3 & & 9.5 \\
\hline & 1550 & 140.9 & 125.0 & & 8.0 \\
\hline & 1590 & 214.9 & 141.6 & & 36.6 \\
\hline & 1630 & 233.5 & 190.0 & & 21.7 \\
\hline & 1670 & 449.8 & 185.5 & & 132.2 \\
\hline & 1710 & 225.5 & 118.0 & & 53.7 \\
\hline & 1750 & 286.3 & 234.2 & & 26.0 \\
\hline \multirow{8}{*}{$\begin{array}{c}\mathrm{E}_{2} \mathrm{~s}^{1}+\mathrm{E}_{3} \mathrm{~d}^{3}+ \\
\mathrm{E}_{3} \mathrm{~d}^{\mathrm{LL}} \text { period }\end{array}$} & 1430 & 1072.9 & 938.1 & \multirow{8}{*}{8} & 16.9 \\
\hline & 1470 & 1209.1 & 1089.6 & & 14.9 \\
\hline & 1510 & 1381.1 & 1256.1 & & 15.6 \\
\hline & 1550 & 1378.1 & 1322.3 & & 7.0 \\
\hline & 1590 & 1307.5 & 1206.6 & & 12.6 \\
\hline & 1670 & 1521.5 & 1122.6 & & 49.9 \\
\hline & 1710 & 1592.5 & 1414.2 & & 22.3 \\
\hline & 1750 & 1133.2 & 911.2 & & 27.8 \\
\hline \multirow{4}{*}{$\mathrm{E}_{3} \mathrm{~d}^{2 \mathrm{U}}+\mathrm{E}_{3} \mathrm{~d}^{1}$ period } & 1430 & 1629 & 1615.4 & \multirow{4}{*}{3.4} & 1.1 \\
\hline & 1670 & 398.3 & 396.1 & & 0.7 \\
\hline & 1710 & 384.3 & 334.7 & & 14.6 \\
\hline & 1750 & 322.3 & 274.1 & & 14.2 \\
\hline
\end{tabular}

5 Seal mechanism of the fault system to reservoirs

Great progress has been made in the study of fault sealing problems, mainly in the fault seal mechanism, quantitative evaluation of influencing factors, and fault seal analytical methods. Fault sealing refers to the differences in the displacement pressure due to the difference in lithology and physical properties of the rocks of hanging wall and footwall or fault zone, thereby preventing fluid migration along the fault zone. This includes the lateral and vertical sealing of the fault (Roald et al, 2007). Whether the fault was sealed in the vertical and lateral directions largely depended on the lithology of the fault zone and the lithologies of rocks adjacent to the fault at both sides. The lateral seal mechanism of the fault was divided into three patterns: sand-shale joint, 


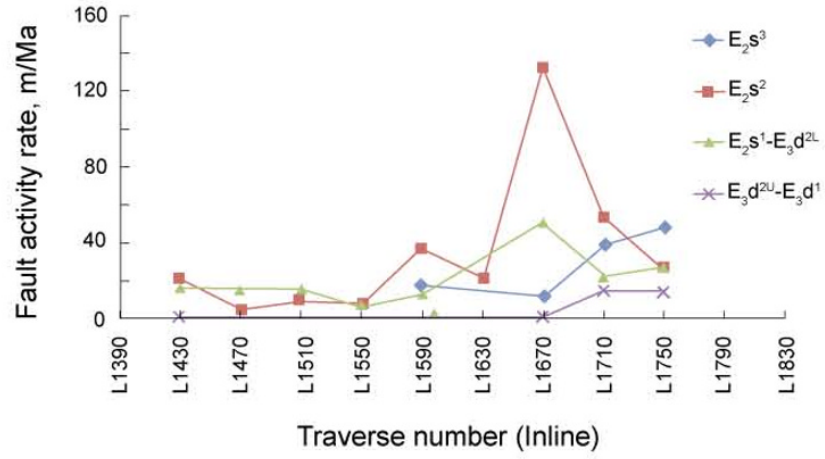

Fig. 4(a) Fault activity rate of No. 1 fault of Liaoxi

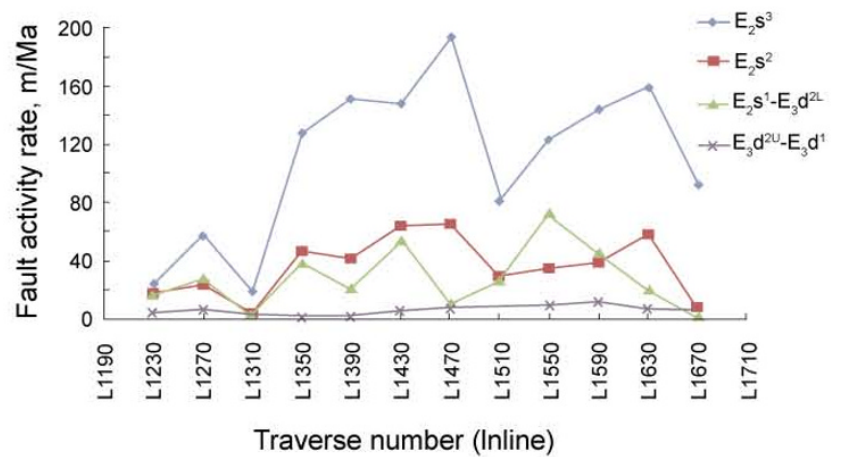

Fig. 4(b) Fault activity rate of No. 2 fault of Liaoxi

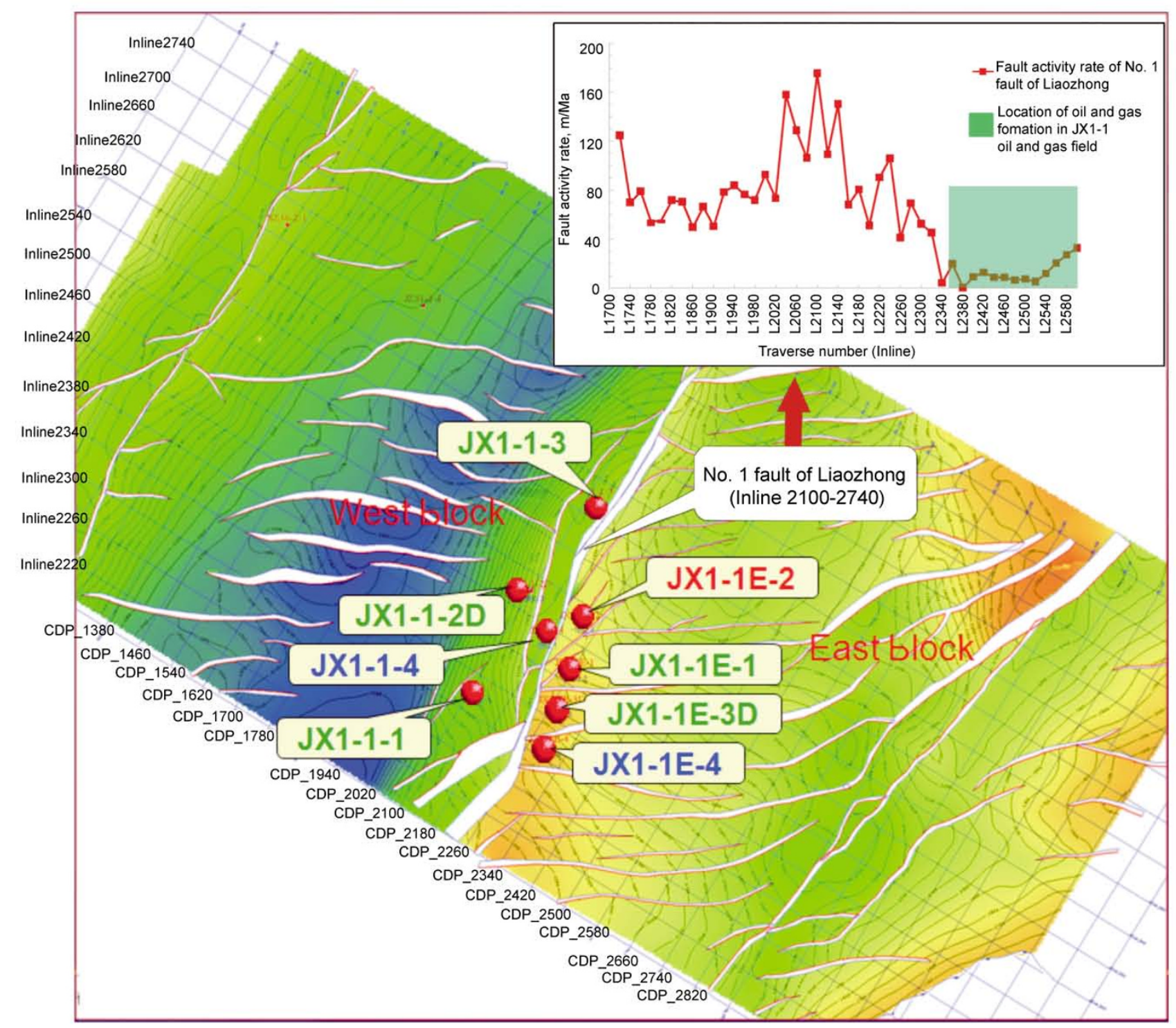

Fig. 5 The activity rate of the trunk fault versus its trend $\left(E_{2} s^{1}\right)$

fault zone sealed with high displacement pressure, and the fault sealed by shale smear. However, the main factors influencing the vertical sealing of the fault included the fault normal pressure, the sectional occurrence, the sand-shale ratio of the faulted strata, and the properties of fault fillings (Knott, 1993). The studies showed that when the fault was sealed by sand-shale joint in the lateral direction, the fault was also sealed in the vertical direction (Fu et al, 1998); when the fault was sealed by fault fillings laterally, the fault should also be sealed in the vertical direction (Fu et al, 1998). The Allan section and the triangular juxtaposition diagram were commonly used to analyze the juxtaposition relationship 
between the lithologies of both fault sides in the oil industry (Allan, 1989). However, the shale smear factor (SSF) (Lindsay et al, 1993), smear gouge ratio (SMGR) (Skerlec, 1999), clay smear potential (CSP) (Fulljames et al, 1997; Yielding et al, 1997,1999; Fristad et al, 1997), shale gouge ratio (SGR) (Yielding, 1997), clay content ratio (CCR) (Fulljames et al, 1997, Yielding, 1997) and other parameters have been used to characterize the fault seal behavior.

The fault and part of the major fault with weak activity were beneficial zones for hydrocarbon accumulation. The current hydrocarbon accumulation is dominated by fault sealing. Taking the LD27-2 oil field as an example, a quantitative calculation was conducted on the sealing of part faults. Several methods, such as SGR of the section, CSP, SSF and the sealed hydrocarbon column height of the section, were used to quantitatively evaluate fault sealing. The calculation equations of SGR, CSP and SSF have been described in detail in previous literature (Lindsay et al, 1993). It is worth noting that the most basic parameter among several parameters of fault sealing is the determination of drilling shale content. We have abundant logging data about the Liaozhong Sag, from which the natural gamma curve can used to determine the shale contents of the hanging wall and the footwall. The shale content of stratum had a good correspondence to natural gamma logging attributes, from the shale content can be calculated more reliably. The calculation equation is expressed as follows:

$$
\left\{\begin{array}{l}
V_{\mathrm{sh}}=\frac{2^{G C U R \cdot I_{\mathrm{GR}}}-1}{2^{G C U R}-1} \\
I_{\mathrm{GR}}=\frac{G R-G R_{\min }}{G R_{\max }-G R_{\min }}
\end{array}\right.
$$

where $V_{\mathrm{sh}}$ is the shale content; $I_{\mathrm{GR}}$ is the relative shale content index; $G R$ is the natural gamma value of the target zone, API; $G R_{\max }$ is the natural gamma value of pure shale, API; $G R_{\min }$ is the natural gamma value of pure sand, API; GCUR is the Hilchie index as 3.7 and 2 for Tertiary strata and old strata respectively.

After obtaining the basic parameters, the triangle juxtaposition diagram of the fault was used to represent the changes of SGR, CSP and SSF with fault throws (Fig. 6(a)(c)). According to the SGR value calculated, the empirical relationship was used to estimate the capillary pressure of the fault (Bretan et al, 1997; Sperrevik et al, 2002), so as to estimate the fault-sealed hydrocarbon column height (Fig. 6(d) and (e)).

The calculation results of fault sealing showed a significant difference in seal ability at different depths of the same fault, as well as in sealed hydrocarbon column height. This was also confirmed by actual drilling results. Using the oil-gas-water interface determined on the basis of structural maps, logging interpretation, and test results of the sand, the oil column height of the Dongying Formation reservoir in well LD27-2-1 was calculated (Fig. 7), with the maximum height at $92 \mathrm{~m}$. The fault capillary resistance was greater than the buoyancy generated by the hydrocarbon column height of $92 \mathrm{~m}$, leading to a strong seal ability. However, the hydrocarbon column height of well LD27-2-4 was small and the degree of trap filling is relatively low. This was not due to the lack of hydrocarbon filling, but poor fault sealing. Both calculated and actual data showed that the degree of hydrocarbon enrichment was controlled by fault seal behavior. However, in the active period of the fault, most faults were open, allowing hydrocarbon to flow along them. Figs. 4 and 5 show that the main active periods of faults in

Well:LD27-2-5b VShale log:Vshale Permeability log:GR_Log Juxtaposition: Shale ratio (continuous data)

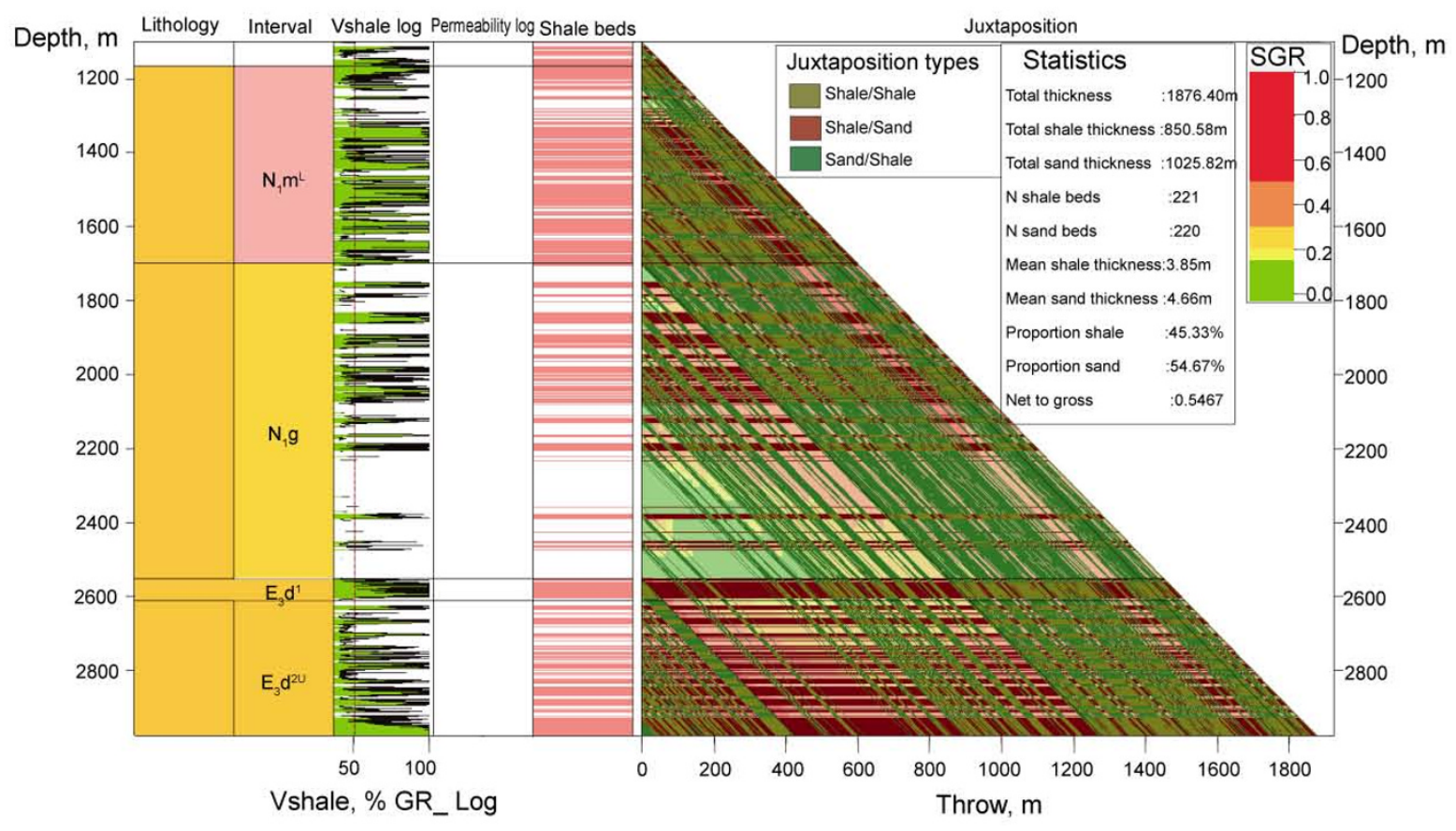

Fig. 6(a) The SGR value of the fractured surface No. 26 in well LD27-2-5b, LD27-2 oil field 
the study area were the lower sedimentary period of the third member of the Shahejie Formation - the second member of the Dongying Formation. Since the sedimentary period of the second member - the first member of the Dongying Formation, the fault activity weakened gradually, mainly shown as thermal subsidence. However, the hydrocarbon generation and expulsion from source rocks occurred mainly from the sedimentary period of the third member of the
Dongying Formation to the present. In fact, the PaleogeneNeogene hydrocarbon filling and accumulation in the Bohai areas also mainly occurred in the later period (Deng, 2001; 2003; Hao et al, 2006; Chen et al, 2006; Zhou et al, 2009). This reveals that after hydrocarbon accumulation, the fault moved at a low rate, showing better fault seal behavior. There was a small possibility of reconstruction and damage of hydrocarbon reservoirs due to faulting.

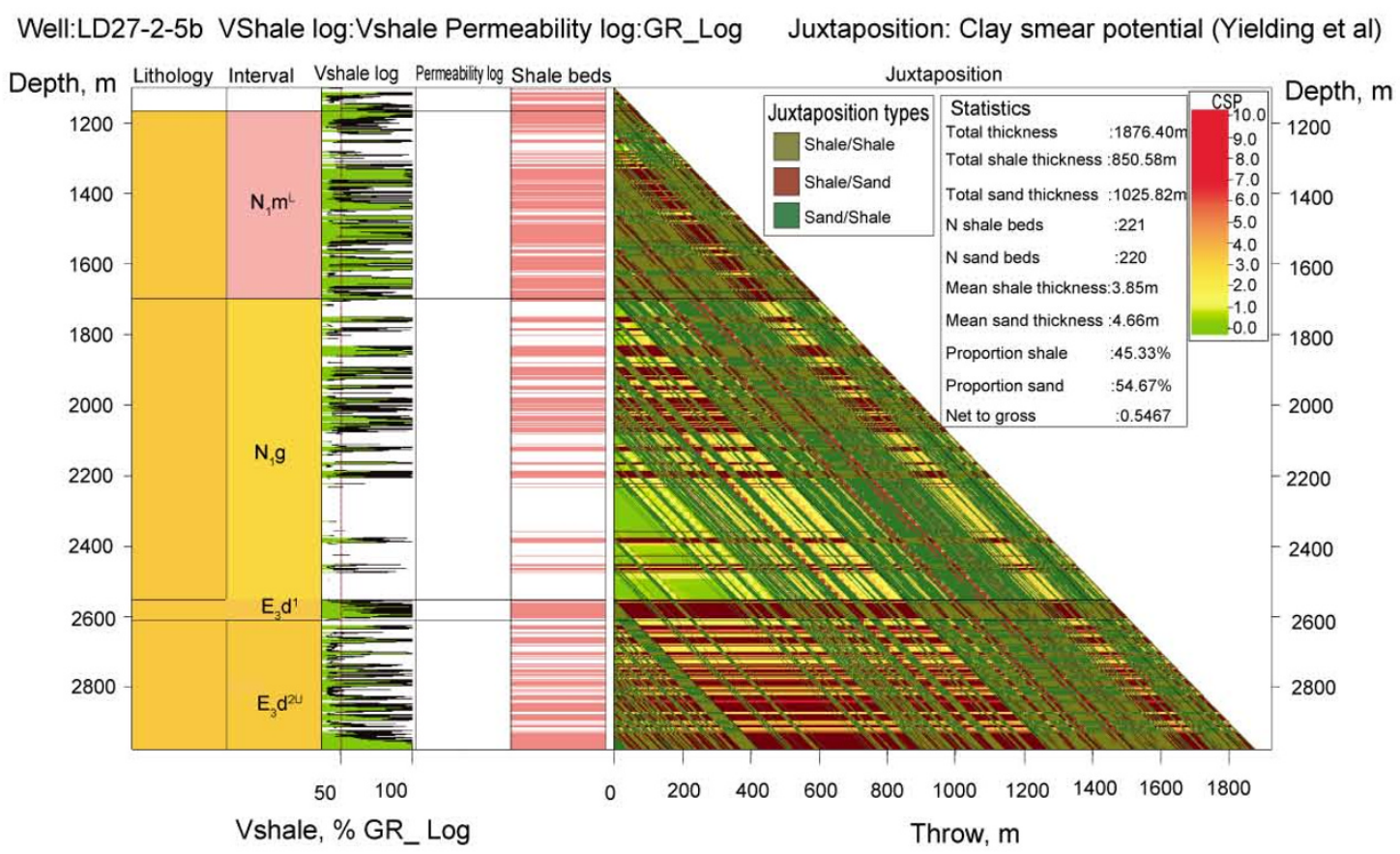

Fig. 6(b) The CSP value of the fractured surface No. 26 in well LD27-2-5b, LD27-2 oil field

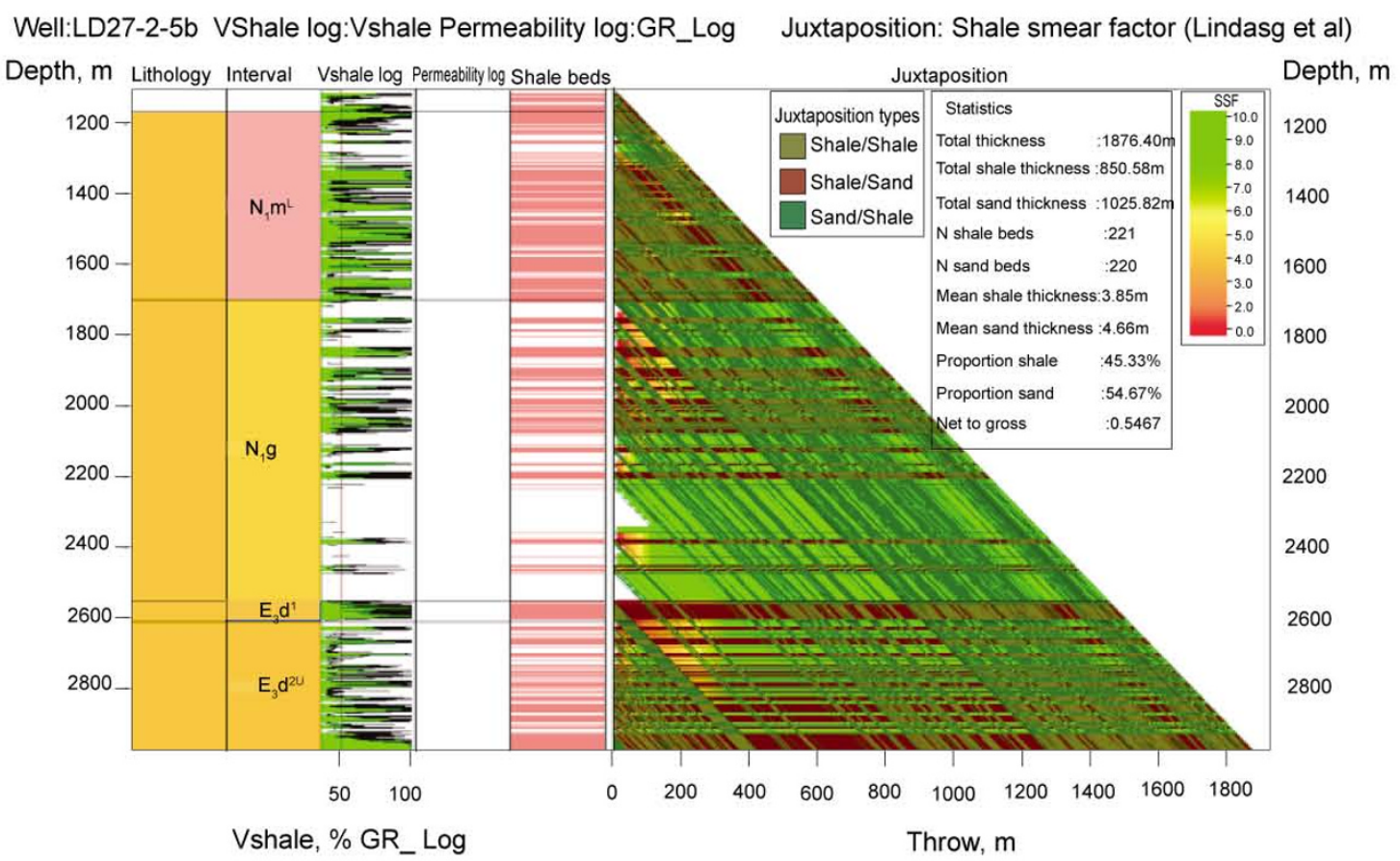

Fig. 6(c) The SSF value of the fractured surface No. 26 in well LD27-2-5b, LD27-2 oil field 


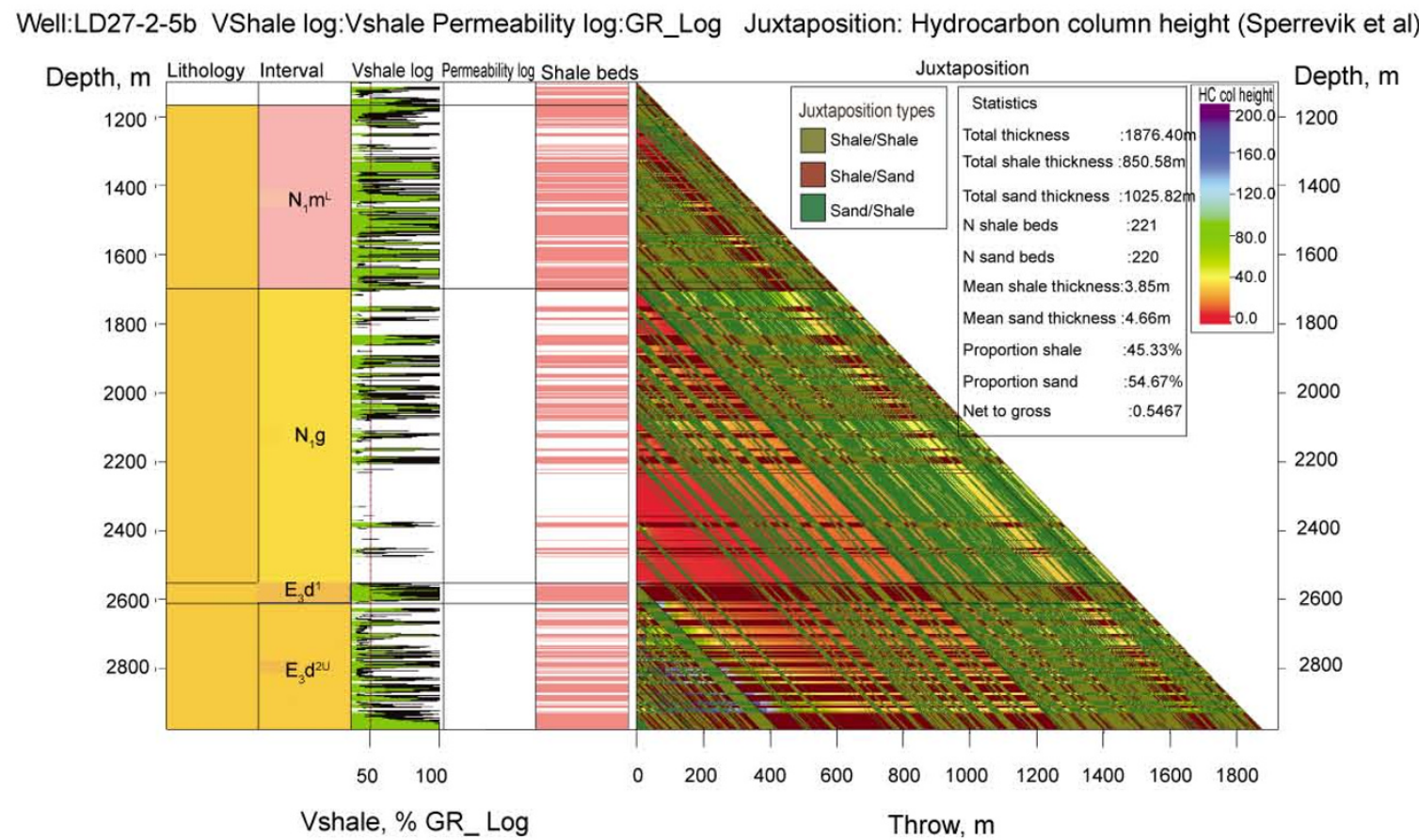

Fig. 6(d) The height of the hydrocarbon column which was sealed off by the fractured surface No. 26 in well-LD27-2-5b, LD27-2 oil field

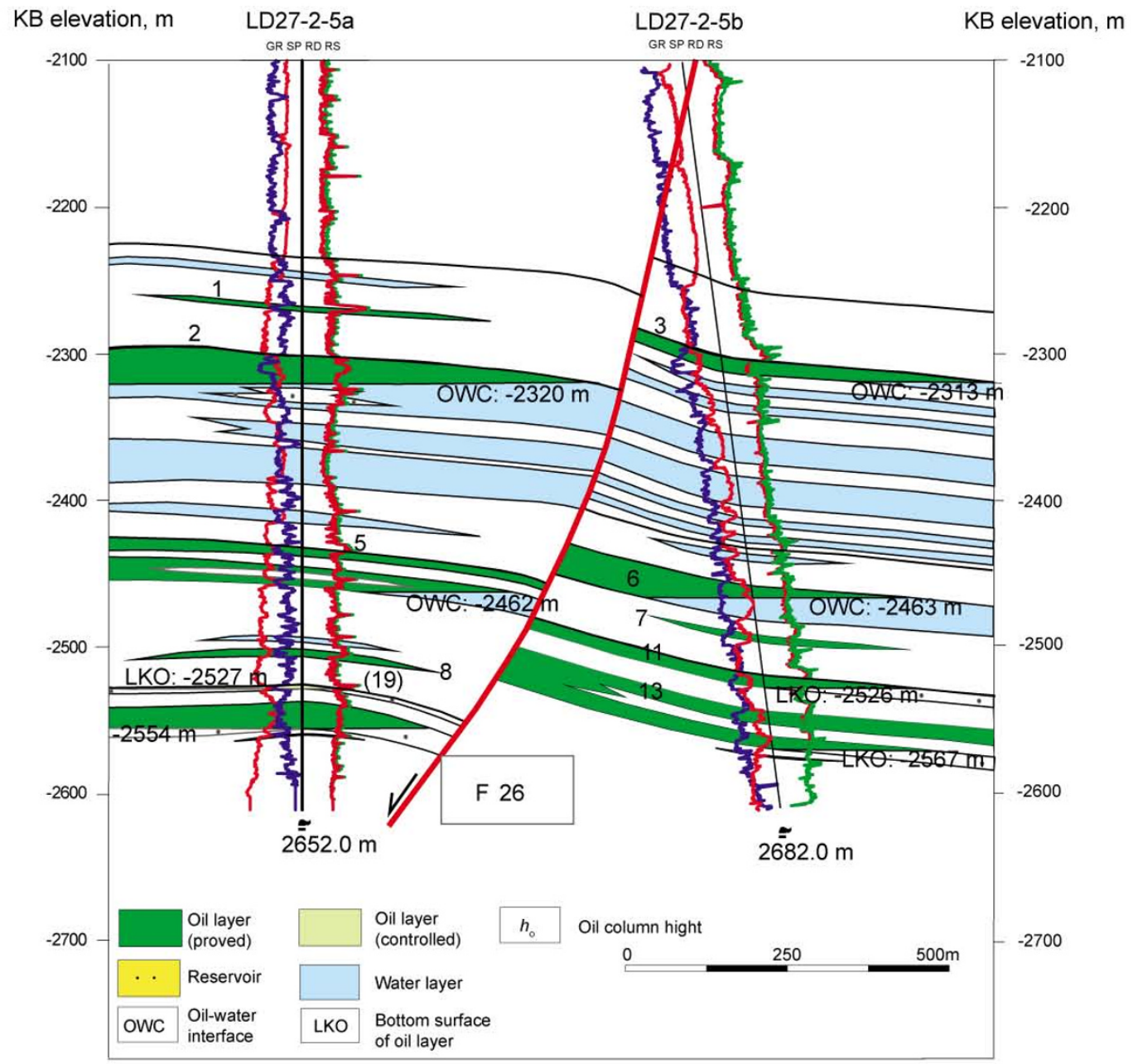

Fig. 6(e) Reservoir section of LD27-2 oil field (Wells LD27-2-5a and LD27-2-5b) 


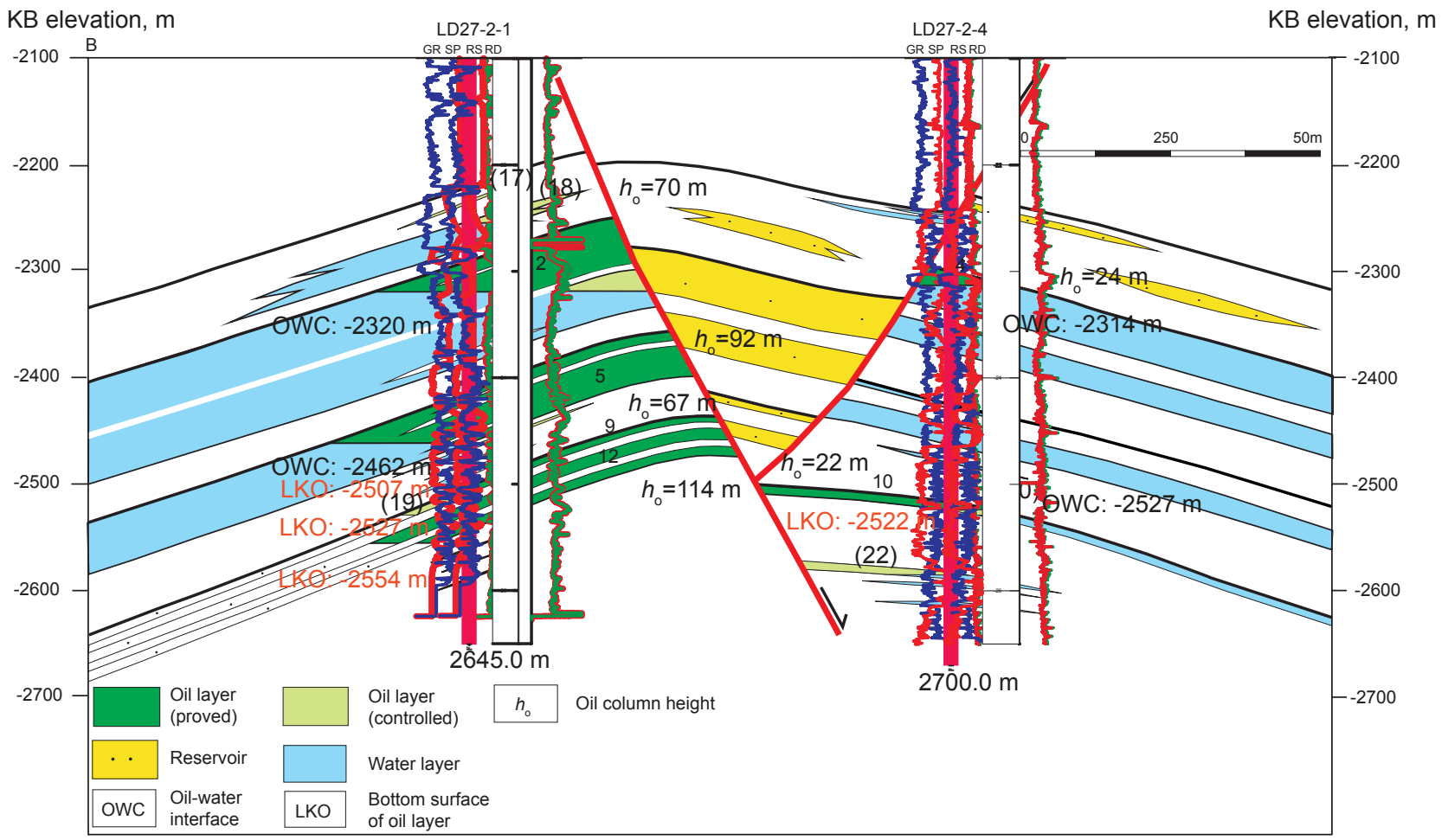

Fig. 7 The height of the hydrocarbon column sealed off by faults in the Dongying Formation, LD27-2 oil field

\section{Conclusions}

The fault system in Liaodong Bay, characterized by clear distinction between the primary and the secondary as well as integration of motion and quietness played a significant role in controlling oil and gas migration and accumulation. Dynamically, the faults of grades I and II were generally active and conducted oil and gas vertically. It was difficult to accumulate oil and gas in these faults; however, oil and gas would accumulate and preserved in some weaklyactive sections. The faults of grade III with low activity rate were favorable for oil and gas accumulation. The fault seal behavior was one of the major factors controlling the oil and gas enrichment. The combination of approaches such as CSP, SSF, SGR, and hydrocarbon column height sealed by the fault plane can lead to effective quantitative calculation of fault seal behavior.

\section{References}

Allan U S. Model for hydrocarbon migration and entrapment within faulted structures. AAPG Bulletin. 1989. 73(7): 803-811

Bekele E, Person M and Marsily G. Petroleum migration pathway and charge concentration: A three dimensional model discussion. AAPG Bulletin. 1999. 83(1): 10-15

Bouvier J D and Kaars-sijp C H. Three dimensional seismic interpretation and fault sealing investigations, Nunriver Field, Nigeria. AAPG Bulletin. 1989. 73 (11): 1397-1414

Bretan P, Yielding G and Jones H. Using calibrated shale gouge ratio to estimate hydrocarbon column heights. AAPG Bulletin. 2003. 87 (3): 383-397

Chen B, Deng Y H, Hao F, et al. Late-stage rapid petroleum accumulation model of BZ34 fault zone in Huanghekou Sag. Acta
Petrolei Sinica. 2006. 27 (1): 37-41 (in Chinese)

Constantin J, Peyaud J B, Vergély P, et al. Evolution of the structural fault permeability in argillaceous rocks in a polyphased tectonic context. Physics and Chemistry of the Earth. 2004. 29(1): 25-41

Deng Y H. Control of the Neotectonism along the Tancheng-Lujiang Fracture Zone on hydrocarbon accumulation in the Eastern Bohai Sea. China offshore Oil and Gas 2001. 15(5): 2-6 (in Chinese)

Deng Y H. Types and accumulation controls of neogene oil reservoirs in Bohai Bay Basin. China offshore Oil and Gas. 2003. 17(6): 4-9 (in Chinese)

Du C H, Hao F, Zou H Y, et al. Progress and problems of faults conduit systems for hydrocarbon migration. Geological Science and Technology Information. 2007. 26(1): 51-56 (in Chinese)

Fristad T, Groth A, Yielding G, et al. Quantitative fault seal prediction: A case study from Oseberg Syd. Norwegian Petroleum Society Special Publications. 1997. 7: 107-124

Fu G, Li F J and Bai M X. An analysis of the relationship between lateral \& vertical sealing of faults. Petroleum Geology \& Oilfield Development in Daqing. 1998. 17(2): 6-9 (in Chinese)

Fulljames J R, Zijerveld L and Franssen R. Fault seal processes: Systematic analysis of fault seals over geological and production time scales. Norwegian Petroleum Society Special Publications. 1997. 7: 51-59

Ghosh K and Mitra S. Structural controls of fracture orientations, intensity, and connectivity, Teton anticline, Sawtooth Range, Montana. AAPG Bulletin. 2009. 93(8): 995-1014

Gong Z S, Cai D S, Zhang G C, et al. Dominating action of the Tanlu Fault on hydrocarbon accumulation in the eastern Bohai Sea Area. Acta Petrolei Sinica. 2007. 28(4): 1-10 (in Chinese)

Hao F, Zhou H Y and Gong Z. S. The material and energy effects of Neotectonics/Late-stage Tectonics and petroleum accumulation. Acta Geological Sinica. 2006. 80(3): 424-431 (in Chinese)

Hao F, Zhou X H, Zhu Y M, et al. Charging of the Neogene Penglai 19-3 Field, Bohai Bay Basin, China: Oil accumulation in a young trap in 
an active fault zone. AAPG Bulletin. 2009a. 93(2): 155-179

Hao F, Zhou X H, Zhu Y M, et al. Mechanisms for oil depletion and enrichment on the Shijiutuo uplift, Bohai Bay Basin, China. AAPG Bulletin. 2009b. 93(8): 1015-1037

Kacewicz M, Peters K E, and Curry D J. 2009 Napa AAPG Hedberg Research Conference on Basin and Petroleum Systems Modeling. AAPG Bulletin. 2010. 94(6): 773-789

Knott S D. Fault seal analysis in the North Sea. AAPG Bulletin. 1993. 77(5): 778-792

Lindsay N G, Murphy F C, Walsh J J, et al. Outcrop studies of shale smears on fault surfaces. In Flint S S and Bryant I D (Editors). The Geological Modelling of Hydrocarbon Reservoirs and Outcrop Analogues. International Association of Sedimentologists, Special Publication. 1993. 15: 113-123

Lu X J, Liu H, Hao F, et al. Petroleum migration system and Neogene petroleum accumulation features in the Baxian Sag, Bohai Bay Basin Petroleum Geology \& Experiment. 2010. 32 (3): 258-264 (in Chinese)

Lv Y F and Fu G. Research on sealing ability of fractures. Beijing: Petroleum Industry Press. 2002 (in Chinese)

Mora A, Horton B K, Mesa A, et al. Migration of Cenozoic deformation in the Eastern Cordillera of Colombia interpreted from fission track results and structural relationships: Implications for petroleum systems. AAPG Bulletin. 2010. 94(10): 1543-1580

Qi J F, Deng R J, Zhou X H, et al. The structure of Tanlu Fracture in Cenozoic Basin of Bohai Sea Area. Science in China (Series D: Earth Sciences). 2008. 38(1): 19-29 (in Chinese)

Roald B F, Eivind J and Susanne S. Methodology for risking fault seal capacity: Implications of fault zone architecture. AAPG Bulletin. 2007. 91(9): 1231-1246

Skerlec G M. AAPG Treatise of Petroleum Geology/Handbook of Petroleum Geology: Exploring for oil and gas traps. Chapter 10: Evaluating top and fault seal. 1999. 10-11

Smith D A. Theoretical consideration of sealing and non-sealing faults AAPG Bulletin. 1966. 50(2):363-374

Smith D A. Sealing and non-sealing faults in Louisiana Gulf Coast salt basin. American Association of Petroleum Geologists Bulletin. 1980. 64(2): 145-172

Sperrevik S, Gillespie P A, Fisher Q J, et al. Empirical estimation of fault rock properties. Norwegian Petroleum Society Special Publications. 2002. 11: 109-125

Wan T, Jiang Y L and Ling H X, et al. Quantitative evaluation of fault activity and fault sealing property and its relationship with hydrocarbon migration and accumulation-By taking Caojiazhuang Step-fault Zone in Chexi Sag for Example. Journal of Oil and Gas Technology. 2010. 32 (4): 18-24 (in Chinese)

Weber K J, Mandl G and Lehner W F, et al. The role of faults in hydrocarbon migration and trapping in Nigerian growth fault structures. 10th Annual Society of Petroleum Engineers, Offshore Technology Conference Proceedings. 1978. (4): 2643-2653

Xu T W, Zeng J H, Wei G, et al. The character and significance of hydrocarbon transferring system in Liaodong Bay. Journal of Southwest Petroleum University (Science \& Technology Edition). 2008. 30(5): 69-72 (in Chinese)

Ye J R, Qing H R, Bend S L, et al. Petroleum systems in the offshore Xihu Basin on the continental shelf of the East China Sea. AAPG Bulletin. 2007. 91(8): 1167-1188.

Yielding G, Freeman B and Needham D T. Quantitative fault seal prediction. AAPG Bulletin. 1997. 81(6): 897-917

Yielding G, Overl J A, Byberg G, et al. Characterization of fault zones for reservoir modeling: An example from the Gullfaks Field Northern North Sea. AAPG bulletin. 1999. 83: 925-951

Zhou X H. Study of hydrocarbon transporting-conducting systems and reservoir-forming characteristics of Mid-Northern Liaoxi Low Uplift. Ph.D Thesis. China University of Geosciences. March 2007 (in Chinese)

Zhou X H, Niu C M and Teng C Y. Relationship between faulting and hydrocarbon pooling during the Neotectonic movement around the central Bohai Bay. Oil \& Gas Geology. 2009. 30(4): 469-475 (in Chinese)

(Edited by Sun Yanhua) 